\title{
An Analysis of the Factors That Influence Elders' Choice of Location and Housing
}

\author{
Hülya Öztop ${ }^{1} \&$ Sevinç Şanlı Akkurt ${ }^{1}$ \\ ${ }^{1}$ Department of Family and Consumer Sciences, Faculty of Economic and Administrative Sciences, Hacettepe \\ University, Ankara, Turkey \\ Correspondence: Assoc. Prof. Dr. Hülya Öztop, Department of Family and Consumer Sciences, Faculty of Economic \\ and Administrative Sciences, Hacettepe University, Ankara, Turkey.
}

Received: February 4, 2016

Accepted: March 14, 2016

Online Published: March 18, 2016

doi:10.5430/ijba.v7n2p79

URL: http://dx.doi.org/10.5430/ijba.v7n2p79

\begin{abstract}
This study was aimed at determining the pull and push factors that influence elders' choices of housing and location. The study sample consisted of 150 seniors aged 60 years and older. The participants were selected by using "snowball sampling technique" and were included in a survey. It was found that the rate of participating elders who did not want to move from their current houses was higher than those who did. The rate of females who did not want to move was higher than that of males $(\mathrm{p}<0.001)$. The study results revealed that the most important push factor for elders who moved or considered moving was making plans for the place they wanted to live for the rest of their lives. The mean score of males at this point was found to be higher than that of the females $(\mathrm{p}<0.001)$. The main pulling factor among elders who wanted to stay in their houses was the feeling of security. The mean score of females at this point was higher than that of males $(\mathrm{p}<0.01)$.
\end{abstract}

Keywords: elderly people, choosing location and housing, pull and push factors

\section{Introduction}

A house is a setting that creates a family environment for people of all ages, provides physical and mental freedom, and comprises all dimensions of social life in addition to all kinds of friendships (Kalinkara and Gonen, 1992). The house and its vicinity are the places where elderly people spend a large part of their lives, and they have many memories in these places. Thus, they are particularly important for elderly people. However, sometimes people are obliged to move from their houses in order to satisfy their locality needs, which change in every part of their lives (Tang and Pickard, 2008).

The pull and push element approach by Lee (1966) is one of the most common approaches among social theorists. The push factors are the negative aspects of the original location that encourage one to leave that place, while the pull factors are the positive factors of the new destination (Lee, 1966). A person might move to a new place due to the influence of push factors that reduce their satisfaction with the current house and have a negative influence on life quality along with the pull factors that orient their efforts toward the establishment of a new residence that fits their aspirations and needs (Ozgur, 2009).

The housing needs of elderly citizens are completely different from people of other age groups (Kalinkara and Gonen, 1992). Most elders are willing to stay in their own houses as longer as possible and grow old there (Tang and Pickard, 2008). Likewise, elders in Turkey primarily prefer to live at their own homes (Demirkan-Turel, 2009). In exceptional cases, they cannot live independently in their current homes but must move to a new environment (Simsekkan, 2006).

Not only the facilities and qualities of the houses where elders live but also the services and amenities in the environment are among the positive features that assist elders and their environment (Kalinkara and Arpaci, 2013). If the house and its vicinity are not suitable for the physical capacity and socio-economic level of the elderly person, it will be an obstacle for their freedom and limit the activities in that environment (Tang and Pickard, 2008). The suitability of the living environment helps the elderly to adapt to that environment, feel themselves as a part of it, and find it comfortable and safe. The more they can satisfy their needs, communicate with their friends and attend different activities, the more they can socialize (Akin, 2006). For that reason the house and its vicinity symbolize the 
independence and freedom that influence elders' welfare. Therefore, the influence of housing on welfare is greater in old age than in other periods of life (Tang and Pickard, 2008). However, the majority of elders in Turkey do not live in healthy and safe houses, nor can they benefit from cultural and social facilities if they do not live in healthy houses (Isikhan, 2000). If elders are not satisfied with their houses and neighborhoods, they will not only be isolated from their environment but will also be less active physically, which will lead them to be more inclined to depression since their lives will be limited to their houses. However, if they are provided with safe walkways, shopping malls and health centers that are easy to access, along with recreational facilities and houses built based on the universal architectural principles through suitable urban design, elders will be more satisfied with their houses and will be able to live independently and productively (Sivam and Karuppannan, 2000).

Complaints about houses are the indicators of the level to which a house meets the needs of its resident, which lead to desire and intention to move out (Kulu and Milewski, 2007). An individual who retires after a health professional life may want to go to a place with better living conditions, such as one that offers leisure activities, a warm climate and low population density. However, they might be motivated to move or stay in their current house due to reasons such as alterations in their life cycles, changes in marital status (e.g., becoming a widow/widower) and the deterioration of health. Relatives who provide unofficial care due to physical and mental deficiencies and the desire to be close to their friends or children (Silverstein and Zablotsky, 1996; Carlson, 1998) are also factors. Because the average age of society has increased under the influence of global demographic changes, it has become necessary to create and develop housing suitable for the elderly. It is very important to determine the factors that influence elders' changing needs and preferences regarding their houses and neighborhoods in order to develop service models and policies that will meet the housing demand of the increasing elderly population. Therefore, this study was aimed at determining the pull and push factors that influence elders' choices in regard to housing and location.

\section{Methodology}

This study was a survey and pilot study. The study sample consisted of 150 individuals at 60 years age and above living in Istanbul, Turkey. They were requested to answer a questionnaire. The sample was selected by using the "snowball sampling technique." Gender was main variable used as a criterion by which to identify the pull and push factors in elders' housing and location choices. The findings of the research were assessed by using chi-square analysis, and the independent samples t-test was used to determine any significant differences between the means of the two groups.

\section{Findings and Discussion}

\subsection{General Information about Elders}

Of the participants, $56 \%$ are females and $44 \%$ are males. The average age of the participant elders was $70.77 \pm 0.60$, and their average income was $2.254,70 \pm 1.12 \mathrm{TL}$. Twenty percent $(20 \%)$ of the participants are high-school graduates and $19.3 \%$ are elementary-school graduates. More than half of the participant elders $(60.7 \%)$ are single or have lost their spouses and $85.3 \%$ are retired. Of the participants, $74.7 \%$ of them own their own houses and $43.3 \%$ live on their own. A majority of the participants (49.3\%) said they had lived in the same house for 20 years or more. It is important that the percentage of the participants saying that they have lived in the same house for $0-4$ years is low $(5.4 \%)$.

\subsection{Information on Elders' Choices of House and Location}

As Table 1 indicates, $70 \%$ of the participants stated that they did not consider moving from their houses. Studies by Fletcher et al. (1999), Tanner (2001) and Levenson et al. (2005) proved that elderly people preferred to live in their own houses. Pannel et al. (2012) found that elders are generally satisfied with their current houses and that approximately half of them said they would not consider moving from their houses in the future. Bilgin (1989), Atalay et al. (1992) and Bilgili (2000) conducted studies in Turkey and found that elders preferred to stay in their own houses.

Of the female participants, $82.1 \%$ said they didn't consider moving from their houses, while $54.5 \%$ of the male participants did not consider doing so $(\mathrm{p}<0.001)$ (Table 1). It can be concluded that this difference between males and females results from socio-cultural and economic factors. Particularly, the studies that analyzed the level of satisfaction concerning houses and neighborhoods obtained results that were contradictory in terms of gender (Ozgur, 2009). 
Table 1. Distribution of the elderly according to their consideration of moving out and gender

\begin{tabular}{|c|c|c|c|c|c|c|c|}
\hline \multirow{4}{*}{$\begin{array}{l}\text { EXPLANATORY } \\
\text { VARIABLE } \\
\text { GENDER }\end{array}$} & \multicolumn{7}{|c|}{ CONSIDERING MOVING OUT IN THE FUTURE } \\
\hline & \multicolumn{2}{|c|}{ YES } & \multicolumn{2}{|c|}{ NO } & \multicolumn{2}{|c|}{$\begin{array}{c}\text { TOTAL } \\
\mathbf{N}=\mathbf{1 5 0}\end{array}$} & ANALYSIS \\
\hline & \multicolumn{2}{|c|}{ Number } & \multicolumn{2}{|c|}{$\%$} & \multicolumn{2}{|l|}{ Number } & \multirow[b]{2}{*}{$\begin{array}{l}\text { Chi-square } \\
\text { analysis }\end{array}$} \\
\hline & 15 & 17.9 & 69 & 82.1 & Number & $\%$ & \\
\hline Female & 30 & 45.5 & 36 & 54.5 & 84 & 100.0 & \multirow{3}{*}{$\begin{array}{r}\mathrm{x}^{2}=13.404 \\
\mathrm{sd}=1, \mathrm{p}<0.001\end{array}$} \\
\hline Male & 45 & 30.0 & 105 & 70.0 & 66 & 100.0 & \\
\hline TOTAL & & & & & & & \\
\hline
\end{tabular}

The main push factor that influences elders' moving or intending to move from their houses is the need to make plans about where they want to live for the rest of their lives $(\bar{x}=4.42)$ (Table 2). A study conducted in Australia reached a similar conclusion (Skladzien and O'Dwyer, 2009).

The primary pull factor among elders who preferred to stay in their houses was the fact that they felt safe there $(\bar{x}=4.27$ ) (Table 2). The study conducted by Skladzien and O'Dwyer in 2009 revealed that the comfort of their houses was the primary pull factor in the desire to stay in their homes.

Table 2. Mean scores on the primary pull and push factors that are influential in choosing a house

\begin{tabular}{lcclcc}
\hline \multicolumn{1}{c}{$\begin{array}{c}\text { Push Factors } \\
\text { (N=150) }\end{array}$} & $\bar{x}$ & SS & \multicolumn{1}{c}{$\begin{array}{c}\text { Pull Factors } \\
\text { (N=150) }\end{array}$} & $\bar{x}$ & SD \\
\hline $\begin{array}{l}\text { Making plans about where } \\
\text { they want to live for the } \\
\text { rest of their lives }\end{array}$ & 4.42 & 0.89 & Feeling secure & 4.27 & 0.67 \\
\hline $\begin{array}{l}\text { Inappropriate design and } \\
\text { plan }\end{array}$ & 3.98 & 1.56 & $\begin{array}{l}\text { Being accustomed to the } \\
\text { house and neighborhood; } \\
\text { having memories }\end{array}$ & 4.26 & 0.64 \\
\hline $\begin{array}{l}\text { The will to change their } \\
\text { life styles }\end{array}$ & 3.91 & 0.95 & $\begin{array}{l}\text { Quality of the location of } \\
\text { the house }\end{array}$ & 4.17 & 0.80 \\
\hline
\end{tabular}

An analysis of the mean scores on the push factors in elders' moving or wishing to move from their houses, regarding gender, showed that "making plans about where they want to live for the rest of their lives" was the primary factor among both males and females. The mean score of males at this point is $(\bar{x}=4.73)$ higher than that of females $(\bar{x}=3.80)(\mathrm{p}<0.001)($ Table 3$)$.

Males' mean score on "wishing to change the current lifestyle", which had been claimed to be influential on the desire to move, was found to be $(\bar{x}=4.17)$, which was higher than that of females $(\bar{x}=3.40)(\mathrm{p}<0.01)$. It is remarkable that males' mean score on the item "the house being too small" $(\bar{x}=1.30)$ is higher than that of females $(\bar{x}=1.00)(\mathrm{p}<0.05)$. It was also found that the mean score of males saying they moved out or wanted to move out because of "pressure and demands of family" ( $\bar{x}=2.87)$ was higher than that of females $(\bar{x}=1.80)(\mathrm{p}<0.05)$ (Table 3$)$.

It was found that the mean score of females saying they moved or wished to move from their houses since "the garden was too big" $(\bar{x}=1.73)$ was higher than that of males $(\bar{x}=1.30)(\mathrm{p}<0.01)$. Females obtained a higher mean score on "changes and problems related to health" $(\bar{x}=3.60)$ than males $(\bar{x}=2.33)(\mathrm{p}<0.05)$. Mean score of females stating that they moved or wanted to move due to "loss of spouse or roommate" ( $\bar{x}=3.67)$ is higher than that of males $(\bar{x}=1.93)(\mathrm{p}<0.01)$. Mean score of females expressing "a liking for moving and change" $(\bar{x}=2.33)$ is higher than that of males $(\bar{x}=1.67)(\mathrm{p}<0.05)$. Similarly, the mean scores of females stating that they wanted to move due to "neighbors changed" (female $(\bar{x}=3.27)(\bar{x}=2.03)(\mathrm{p}<0.05)$ ), "dislike for current location" (female $(\bar{x}=2.80)$ male $(\bar{x}$ $=1.47)(\mathrm{p}<0.001))$ or "feeling of loneliness and isolation" (female $(\bar{x}=2.87)$ male $(\bar{x}=1.43)(\mathrm{p}<0.001))$ is higher than those of males' (Table 3). 
An analysis of the pull factors among elders who stayed or wished to stay in their houses according to gender showed that the feeling of security was dominant among females $(\bar{x}=4.39)$, while being used to the location and house and having memories were dominant among males $(\bar{x}=4.33)$ (Table 4).

Table 3. Mean scores on push factors that influence elders' moving or wishing to move from their houses by gender

\begin{tabular}{|c|c|c|c|c|c|}
\hline \multirow{3}{*}{$\begin{array}{l}\text { The Push Factors that } \\
\text { Influence Elders in Moving or } \\
\text { Willing to Move from their } \\
\text { Houses } \\
\qquad(\mathrm{N}=45)\end{array}$} & \multicolumn{4}{|c|}{ GENDER } & \multirow{3}{*}{ ANALYSIS } \\
\hline & \multicolumn{2}{|c|}{$\begin{array}{c}\text { Female } \\
n=15\end{array}$} & \multicolumn{2}{|c|}{$\begin{array}{l}\text { Male } \\
\mathbf{n}=\mathbf{3 0}\end{array}$} & \\
\hline & $\bar{x}$ & SS & $\bar{x}$ & SS & \\
\hline $\begin{array}{l}\text { Making plans about where they } \\
\text { want to live for the rest of their } \\
\text { lives }\end{array}$ & 3.80 & 1.21 & 4.73 & 0.45 & $\mathrm{t}=-3.776 * * *$ \\
\hline $\begin{array}{l}\text { Wishing to change their } \\
\text { lifestyles }\end{array}$ & 3.40 & 1.24 & 4.17 & 0.65 & $\mathrm{t}=-2.736 * *$ \\
\hline $\begin{array}{l}\text { Wishing to be close to family } \\
\text { and friends }\end{array}$ & 2.60 & 2.03 & 2.33 & 1.42 & $\mathrm{t}=0.513$ \\
\hline Being retired & 2.07 & 0.80 & 2.60 & 1.73 & $\mathrm{t}=-1.128$ \\
\hline $\begin{array}{l}\text { Difficulties related to the care } \\
\text { and repair of the house and } \\
\text { garden }\end{array}$ & 3.53 & 1.64 & 3.67 & 1.81 & $\mathrm{t}=-0.240$ \\
\hline The garden being too big & 1.73 & 0.46 & 1.30 & 0.47 & $\mathrm{t}=2.957 * *$ \\
\hline Costs/financial reasons & 2.20 & 1.52 & 2.30 & 1.60 & $\mathrm{t}=-0.201$ \\
\hline $\begin{array}{l}\text { Wishing to have more spare } \\
\text { time }\end{array}$ & 2.80 & 1.21 & 2.43 & 1.10 & $\mathrm{t}=1.018$ \\
\hline $\begin{array}{l}\text { Wishing to be close to the } \\
\text { services provided }\end{array}$ & 3.27 & 1.67 & 2.93 & 0.98 & $\mathrm{t}=0.846$ \\
\hline The house being too big & 2.60 & 2.03 & 1.80 & 1.35 & $\mathrm{t}=1.579$ \\
\hline Issues related to safety/security & 2.60 & 2.03 & 2.33 & 1.42 & $\mathrm{t}=0.513$ \\
\hline $\begin{array}{l}\text { Changes and problems related to } \\
\text { health }\end{array}$ & 3.60 & 1.68 & 2.33 & 1.77 & $\mathrm{t}=2.301 *$ \\
\hline Inappropriate design and plan & 3.53 & 1.64 & 4.20 & 1.50 & $\mathrm{t}=-1.365$ \\
\hline $\begin{array}{l}\text { Loss of physical power to do the } \\
\text { house chores }\end{array}$ & 3.27 & 1.67 & 3.10 & 1.67 & $t=0.316$ \\
\hline Loss of spouse/roommate & 3.67 & 1.95 & 1.93 & 1.46 & $\mathrm{t}=3.349 * *$ \\
\hline $\begin{array}{l}\text { Not wishing to be a burden on } \\
\text { family }\end{array}$ & 3.13 & 1.25 & 2.60 & 1.65 & $\mathrm{t}=1.101$ \\
\hline Liking for moving out or change & 2.33 & 0.49 & 1.67 & 1.03 & $\mathrm{t}=2.371 *$ \\
\hline Neighbors changed & 3.27 & 1.71 & 2.03 & 1.35 & $\mathrm{t}=2.639 *$ \\
\hline Dislike for the location & 2.80 & 1.37 & 1.47 & 0.78 & $\mathrm{t}=4.175 * * *$ \\
\hline $\begin{array}{l}\text { Wishing to live together with } \\
\text { others of the same age }\end{array}$ & 2.47 & 1.64 & 2.20 & 1.27 & $t=0.601$ \\
\hline The house being too small & 1.00 & 0.00 & 1.30 & 0.47 & $\mathrm{t}=-2.478 *$ \\
\hline Dislike for the neighbors & 1.53 & 0.92 & 1.43 & 0.50 & $\mathrm{t}=0.474$ \\
\hline $\begin{array}{l}\text { Pressure and demands of the } \\
\text { family }\end{array}$ & 1.80 & 1.37 & 2.87 & 1.63 & $\mathrm{t}=-2.170 *$ \\
\hline $\begin{array}{l}\text { Feelings of isolation and } \\
\text { loneliness }\end{array}$ & 2.87 & 1.85 & 1.43 & 0.50 & $\mathrm{t}=4.004 * * *$ \\
\hline
\end{tabular}


It was found that the mean score of females on "feeling secure" $(\bar{x}=4.39)$ was higher than that of males $(\bar{x}=4.00)$ $(p<0.01)$. It is remarkable that the scores of females saying they stayed or wanted to stay in their homes due to "Having the economic power to afford the costs of their current house" (female $(\bar{x}=3.52)$ male $(\bar{x}=2.61)(\mathrm{p}<0.001)$ ), "the house having an appropriate size" (female $(\bar{x}=4.38)$ male $(\bar{x}=2.89)(\mathrm{p}<0.001)$ ), "the house and garden being easy to take care of" (female $(\bar{x}=3.39)$ male $(\bar{x}=2.03)(\mathrm{p}<0.001)$, "the plan and design of the house supporting the needs of elderly years" (female $(\bar{x}=2.86)$ male $(\bar{x}=2.39)(\mathrm{p}<0.05)$ ), "the difficulty of moving out" (female $(\bar{x}=2.51)$ male $(\bar{x}=1.75)(\mathrm{p}<0.01))$, "having health problems" female $(\bar{x}=2.99)$ male $(\bar{x}=1.97)(\mathrm{p}<0.01))$ is higher than that of males. The mean scores of males saying that they wanted to stay in their houses "only because it a family inheritance" $(\bar{x}=3.28)$ is higher than that of females $(\bar{x}=2.58)(\mathrm{p}<0.05)$ (Table 4$)$.

Table 4. The mean scores on pull factors that elders stayed or wanted to stay in their houses

\begin{tabular}{|c|c|c|c|c|c|}
\hline \multirow{3}{*}{$\begin{array}{l}\text { Pull Factors Among Elders } \\
\text { Who Stay or Want to Stay in } \\
\text { Their Houses } \\
\qquad(\mathrm{N}=105)\end{array}$} & \multicolumn{4}{|c|}{ GENDER } & \multirow{3}{*}{ ANALYSIS } \\
\hline & \multicolumn{2}{|c|}{$\begin{array}{c}\text { Female } \\
n=69\end{array}$} & \multicolumn{2}{|c|}{$\begin{array}{l}\text { Male } \\
n=36\end{array}$} & \\
\hline & $\bar{x}$ & SS & $\bar{x}$ & SS & \\
\hline The house being comfortable & 4.04 & 0.11 & 3.72 & 0.16 & $\mathrm{t}=1.690$ \\
\hline $\begin{array}{l}\text { Having economic power to } \\
\text { afford the costs of the house }\end{array}$ & 3.52 & 0.13 & 2.61 & 0.25 & $\mathrm{t}=3.649 * * *$ \\
\hline $\begin{array}{l}\text { The house having a favorable } \\
\text { location }\end{array}$ & 4.26 & 0.09 & 4.00 & 0.14 & $\mathrm{t}=1.594$ \\
\hline Feeling safe and secure & 4.39 & 0.08 & 4.00 & 0.10 & $\mathrm{t}=3.116 * *$ \\
\hline $\begin{array}{l}\text { The house having a preferable } \\
\text { location/ the services being easy } \\
\text { to access }\end{array}$ & 4.03 & 0.10 & 4.17 & 0.12 & $\mathrm{t}=-0.885$ \\
\hline $\begin{array}{l}\text { Liking for neighborhood and } \\
\text { having favorable neighbors }\end{array}$ & 3.68 & 0.20 & 2.17 & 0.25 & $\mathrm{t}=4.567 * * *$ \\
\hline $\begin{array}{l}\text { The house having an appropriate } \\
\text { size }\end{array}$ & 4.38 & 0.08 & 2.89 & 0.22 & $\mathrm{t}=7.753 * * *$ \\
\hline $\begin{array}{l}\text { The house/garden being easy to } \\
\text { take care of }\end{array}$ & 3.39 & 0.10 & 2.03 & 0.24 & $\mathrm{t}=6.109 * * *$ \\
\hline $\begin{array}{l}\text { The plan and design of the house } \\
\text { meeting the needs of the elderly }\end{array}$ & 2.86 & 0.11 & 2.39 & 0.23 & $\mathrm{t}=2.074 *$ \\
\hline $\begin{array}{l}\text { The garden being spacious } \\
\text { enough }\end{array}$ & 2.35 & 0.11 & 2.56 & 0.28 & $\mathrm{t}=-0.814$ \\
\hline $\begin{array}{l}\text { The house being close to family } \\
\text { and friends }\end{array}$ & 3.42 & 0.21 & 3.56 & 0.25 & $\mathrm{t}=-0.401$ \\
\hline $\begin{array}{l}\text { The house being a family } \\
\text { inheritance }\end{array}$ & 2.58 & 0.19 & 3.28 & 0.31 & $\mathrm{t}=-1.989 *$ \\
\hline The difficulty of moving out & 2.51 & 0.18 & 1.75 & 0.17 & $\mathrm{t}=2.698 * *$ \\
\hline $\begin{array}{l}\text { Being used to the location and } \\
\text { house; having memories }\end{array}$ & 4.23 & 0.09 & 4.33 & 0.08 & $\mathrm{t}=-0.736$ \\
\hline Experiencing health problems & 2.99 & 0.19 & 1.97 & 0.24 & $\mathrm{t}=3.243 \quad * *$ \\
\hline
\end{tabular}

\section{Conclusion and Suggestion}

The quality and order of the house elders live in are important for their welfare (Ilce et al., 2006). When elders' living environments are designed taking their functional competencies into consideration, they can independently perform their daily activities with little or no support (Simsekkan, 2006). However, the living area is not limited to the house; 
the location, neighbors and elders' experiences are as important as the house they live in (Perez et al., 2001). For this reason, services and amenities near elders' houses are accepted as objective qualities contributing to them like demographic, social and economic characteristics (Kalinkara and Arpaci, 2013). This study was aimed at determining the pull and push factors that influence the choices of location and housing in the elderly years. The results are shown below:

Seventy percent $(70 \%)$ of elders do not consider moving from their current houses. The percentage of females who do not consider moving $(82.1 \%)$ is higher than that of males $(54.5 \%)(\mathrm{p}<0.001)$.

The main push factor that influences elders to move or want to move from their current houses is the need to make plans about where they want to live for the rest of their lives $(\bar{x}=4.42)$. For this item, the mean score of males $(\bar{x}=$ $4.73)$ is higher than that of the females $(\bar{x}=3.80)(\mathrm{p}<0.001)$.

The primary pull factor that influences elders to stay or want to stay in their houses is that they feel safe and secure $(\bar{x}=4.27)$. For this item, the mean score of females $(\bar{x}=4.39)$ is higher than that of males $(\bar{x}=4.00)(\mathrm{p}<0.01)$. As the research results indicate, the majority of the participating elders prefer to grow old in their own houses. Accordingly, a study conducted by Oztop and Aydiner (2013) in collaboration with adults in the pre-retirement period living in Ankara obtained similar results. The participant adults said they wanted to stay where they lived after they retired. This result was similar to those reached by foreign studies, and it puts forward the demands of individuals in our country.

If innovative and flexible service models are developed, these demands of individuals to grow old where they live would be satisfied and it would help meet their needs. For that reason the houses designed for elders should have certain qualities such as the protection of social relationships; the creation of a safe and secure environment and the ability to meet physical, social and mental needs and wishes. Moreover, arrangements that allow elders to be part of the society and creating alternatives based on universal design principles giving them the chance to grow old in their own homes and giving them an option will serve to enhance the quality of life.

\section{References}

Akin, G. (2006). Old Age with All Dimensions. Ankara: Palme Publishing.

Atalay, Y., et al. (1992). A Study of Turkish Family Structure. Ankara: DPT Publishing.

Bilgili, N. (2000). Determination of the Problems Experienced by Families Providing Care to the Elder. (Unpublished doctoral dissertation). Hacettepe University Institute of Health Sciences, Ankara.

Bilgin, O. (1989). An Analysis of Housing Preferences Among the Elderly. Unpublished Master on Sciences dissertation. Hacettepe University Institute of Health Sciences, Ankara.

Carlson, J. E., Junk, V. W., Fox, L. K., Rudzitis, G., \& Cann, S. E. (1998). Factors Affecting Retirement Migration to Idaho: An Adaptation of the Amenity Retirement Migration Model, The Gerontological Society of America The Gerontologist, 38(1), 18-24.

Demirkan-Turel, G. (2009). Urban life and old age. Past, Present and Future Old age. Yaslilik Platformu Publishing No. 1, Ankara.

Fletcher, P., Riseborough, M., Humphries, J, Kenkins, C., \& Whittingham, P. (1999). Citizenship and Services in Older Age: The Strategic Role of Very Sheltered Housing. Beaconsfield: Housing 21.

Ilce, O. A., Ilce, C. A., \& Diramali, A. (2006). Prevention of domestic accidents among elders and interior space analyses regarding the prevention of domestic accidents. Hacettepe University, Sociological Researches e-journal. Retrieved 7 December 2014, from http://www.sdergi.hacettepe.edu.tr/aiciad

Işıkhan, V. (2000). Life Quality of the Elderly. In Erkan, G., \& Isikhan, V. (Eds.), Anthropology and Old Age (pp. 125-135). Ankara: Hacettepe University Social Sciences College Publishing.

Kalinkara, V., \& Arpaci, F. (2013). Getting Old in One's Own House. Karabuk: 7th National Congress of Old Age, May 23-25, 54-60.

Kalinkara, V., \& Gonen, E. (1992). Anthropometric Data- Kitchen Equipment Relation among Elderly Women. Ankara: Ankara University Faculty of Agriculture Publishing: 1262, Scientific Researches and Analyses: 697.

Kulu, H., \& Milewski, N. (2007). Family change and migration in the life course: An introduction. Demographic Research, 17, 567-590. http://dx.doi.org/10.4054/DemRes.2007.17.19

Lee, E. S. (1966). A Theory of Migration. Demography, 3(1), 47-57. 
Levenson, R, Jeyasingham, M., \& Joule, N. (2005). Looking Forward to Care in Old Age; Expectations of the next generation, London, King's Fund. Retrieved October 5, 2014, from http://www.kingsfund.org.uk/resources/publications/looking_forward.html

Ozgur, E. M. (2009). Satisfaction with Residence and Urban Residence Movements. Journal of Geographical Sciences, 7(2), 111-127.

Oztop, H., \& Aydiner, A. (2013). Factors affecting the decision to "Age In Place" in post-retirement. The International Journal of Interdisciplinary Social Sciences, 7(2), 73-88.

Pannel, J., Aldridge, H., \& Kenway, P. (2012). Older People's Housing. Choice, Quality of Life and Under Occupation. Joseph Rowntree Foundation Publication. Retrieved October 4, 2014, from http://www.jrf.org.uk/publications/older-peoples-housing-choice

Perez, F. R., Fernandez-Mayoralas, G., Rivera, F. E. P., \& Abuin, J. M. R. (2001). Aging in place: Predictors of the residential satisfaction of elderly. Social Indicators Research, 54, 173-208.

Silverstein, M., \& Zabrotsky, D. L. (1996). Health and Social Precursors of Later Life Retirement-Community Migration. Journal of Gerontology: Social Sciences, 51B(3), 150-156. http://dx.doi.org/10.1093/geronb/51B.3.S150

Şimşekkan, G. (2006). Industrial Product Design for Elderly People in Interior Spaces, Graduate School of Engineering and Sciences of Izmir Institute of Technology. Unpublished master of science dissertation, Izmir.

Sivam, A., \& Karuppannan, S. (2000). Factors Influencing Old Age Persons' Residential Satisfaction: A case study of South Australia. Sociology Conference, University of South Australia.

Skladzien, E., \& O'Dwyer, S. (2009). Moving or staying put: Deciding where to live in later life. Australian Government Department of Health and Aging, Australia.

Tang, F., \& Pickard, J. G. (2008). Aging in place or relocation: Perceived awareness of community-based long-term care and services. Journal of Housing for the Elderly, 22(4), 404-422. http://dx.doi.org/10.1080/02763890802458429

Tanner, D. (2001). Sustaining the self in later life: Supporting older people in the community. Aging and Society, 21, 255-278. http://dx.doi.org/10.1017/S0144686X01008248 